\title{
Editorial \\ Frente al COVID-19 ¿A quién siguen los políticos?
}

\author{
José Manuel Álvarez ZÁrate \\ jose.alvarez@uexternado.edu.co
}

Los gobiernos que han caído en el falso dilema entre salud y economía han implementado políticas y regulaciones contradictorias e ineficientes, afectando gravemente el aparato económico y la institucionalidad. Al final, no se ha podido detener las muertes diarias.

A nivel global, en el manejo de la pandemia del COVID-19 las recomendaciones de los médicos y científicos de la Organización Mundial de la Salud - OMS han jugado un papel preponderante en las políticas de los países ${ }^{1}$. Detener e interrumpir la transmisión del virus y atender sus consecuencias es su papel. Por ello, no atienden los efectos económicos y sociales de sus políticas. Otras instituciones internacionales, como la Organización Mundial del Comercio - OMC, el Fondo Monetario Internacional - FMI, la Comisión Económica para América Latina y el Caribe - CEPAL o la Organización de las Naciones Unidas para la Alimentación y la Agricultura - FAO (por su sigla en inglés) se limitan a llevar las cuentas de los efectos comerciales, económicos y sociales de las medidas sanitarias. Coinciden en la recomendación de mantener esfuerzos para revertir la destrucción de riqueza, desempleo y pérdida de ingresos de millones de personas en todo el mundo. Los economistas y médicos, asesores de gobiernos, no integran el panorama completo.

Las cifras de muertos y contagiados que anuncia la OMS suben todos los días², al igual que la pérdida de riqueza, inversión y puestos de trabajo. Según la CEPAL, América Latina sufrirá más que los países desarrollados los efectos del confinamiento. En Colombia ${ }^{3}$, el $80 \%$ de los hogares han visto reducidos sus ingresos y cerca de

DOI: https://doi.org/10.18601/01236458.n53.01

1 WHO, Strategic preparedness and response plan, 3 de febrero de 2020; OMS, Directrices de planificación operativa para ayudar al desarrollo de planes de acción nacionales, 12 de febrero de 2020 y Marco para la toma de decisiones: puesta en práctica de campañas de vacunación masiva durante la covid-19, 22 de mayo de 2020.

2 Al 7 de agosto de 2020, 702.642 muertos.

3 El comercio global cae 32\%; mientras que en América Latina la caída de la producción llegará a $9,1 \%$, en Colombia 9,4\% y el desempleo ya ronda el 25\% en 13 ciudades. La FAO también señala que 
6.000.000 de personas no tienen empleo. Estas son personas de carne y hueso que perdieron su ingreso para sobrevivir y que las cifras diarias de muertos esconden. El impacto mediático de las 7.129 muertes $^{4}$ esconde el drama de los desempleados, de los que no pueden comer más de una vez al día. En América Latina, 54,7 millones de personas se encuentran en estado de inseguridad alimentaria ${ }^{5}$, que produce retroceso en el crecimiento y bajo peso al nacer de millones de niños, como advierte la FAO, que les afectará de por vida. Los que mueren, terminan su sufrimiento en pocos días, pero los cientos de millones de personas (empresarios, vecinos, trabajadores informales, etc.) sufrirán por recomendación médica por varios años.

En este contexto, Colombia anuncia políticas para detener las muertes, promesa imposible de cumplir, mientras que las medidas económicas, con alta dosis retórica y baja efectividad, generan problemas adicionales en la institucionalidad. La exagerada cantidad de normas de emergencia por el COVID-19 (más de 120 decretos y cientos de reglamentaciones ejecutivas), ya muestra resultados negativos frente a: i) el costo institucional-democrático, institucional-eficiente e institucional-administrativo; ii) en la reducida calidad y competitividad regulatoria del país; iii) su incapacidad de mejorar el desempeño económico, y iv) las consecuencias negativas de la excesiva regulación inefectiva. En toda la política se extraña un plan para fortalecer los sistemas de salud de forma permanente y una política industrial a largo plazo.

A pesar de que la OCDE ve en la crisis la posibilidad para que los gobiernos mejoren la calidad de la política regulatoria y profundicen en la dimensión territorial, aquí se pierde esa oportunidad. Los intereses políticos del gobierno, por un lado, impiden reforzar la coordinación con las autoridades locales para fortalecer la comunicación, la recopilación de datos, gestionar el impacto en las finanzas locales y, por otro, flexibilizar procedimientos administrativos, incluido el pago de impuestos, apoyar a las PYMES flexibilizando los requisitos para iniciar una empresa, así como simplificar las normas en materia de contratación pública, entre otras.

Los más de 120 decretos tratan una innumerable cantidad de cuestiones de diversa naturaleza, entre otras, restricciones al transporte aéreo y terrestre, creación de programas de subsidios, medidas sobre la inversión y enajenación de activos del Estado, exenciones, devolución y creación de nuevos impuestos, nuevas reglas sobre el funcionamiento de la rama judicial, modificaciones en materia de procesos de insolvencia, cambios en el régimen de contratación estatal, medidas para terminar unilateralmente contratos comerciales.

Los costos y beneficios de este centenar de nuevas regulaciones ya están afectando la institucionalidad, con el consecuente impacto negativo en la competitividad y en la calidad regulatoria del país. Según los índices de gobernanza y política regulatoria $i R e g$

la recuperación tiene un ritmo desigual y más lento en los países más pobres. El Estado de Seguridad Alimentaria y Nutrición en el Mundo (2019).

$4 \quad$ Dato de la OMS al 7 de agosto.

5 En América Latina están subalimentadas 34,7 millones, en peligro grave 9 millones. Personas que suelen quedarse sin alimentos y pueden pasar un día (o varios) sin comer. 
de la OCDE (2018), respecto a: la participación de los interesados en la elaboración de la regulación, evaluación del impacto de la reglamentación (RIA), evaluación ex post de la regulación, Colombia se encontraba debajo del promedio de los países de la OCDE en calidad regulatoria ${ }^{6}$. En similar sentido, en el informe global de competitividad de la regulación Doing Business, Colombia ha retrocedido año a año posiciones en el ranking: de la posición 37 en 2010, cayó al puesto 67 en 2020, con una pésima calificación en pago de impuestos (puesto 148), comercio transfronterizo (puesto 133) y ejecución de contratos (puesto 177$)^{7}$, subindicadores todos estos que se afectarán a posteriori por el manejo regulatorio de la pandemia.

Otro problema ha sido la descoordinación entre el gobierno nacional y los territorios, evidenciado desde el inicio de la declaratoria de la emergencia. Mientras algunos alcaldes optaron por decretar aislamientos preventivos en sus ciudades, el gobierno nacional decía que dichas medidas no podían tomarse de manera autónoma, sino que debían coordinarse con el gobierno nacional. Lo propio sucedió con el progresivo levantamiento de las medidas de aislamiento. Así, mientras varios municipios y ciudades capitales optaban o presionaban por mantener el aislamiento, el gobierno nacional quería flexibilizar las mismas medidas.

Vemos que la crisis del COVID-19 posee una fuerte dimensión político-territorial y médico-económica, con importantes implicaciones regulatorias de gestión. Golpea de manera diferente a cada país y con mayor impacto en los territorios, como lo señala la $\mathrm{OCDE}^{8}$. En regiones y poblaciones históricamente más vulnerables, donde existen factores diferenciadores, como la exposición de cada localidad a cadenas de valor globales y el tipo de concentración de sus actividades económicas, por ejemplo, el turismo.

6 OECD (2018). Regulatory Policy Outlook, pp. 174-175.

7 World Bank (2020). Doing Business: Measuring Business Regulations, Economy Profile Colombia.

8 OECD (2020). Policy Responses to Coronavirus (covid-19): The territorial impact of covid-19: Managing the crisis across levels of government. 